\title{
The Heterogeneity of Glucan Preparations from the Walls of Various Yeasts
}

\author{
By D. J. MANNERS, A. J. MASSON AND J. C. PATTERSON \\ Department of Brewing and Biological Sciences, \\ Heriot-Watt University, Edinburgh EHI I $H X$
}

(Received 6 July 1973; revised 5 September 1973)

\begin{abstract}
SUMMARY
Previous studies have shown that the insoluble glucan from the walls of baker's yeast (Saccharomyces cerevisiae) is heterogeneous. It consists of about $85 \%$ of an insoluble branched $\beta$-(I $\rightarrow 3$ )-glucan and about $15 \%$ of a soluble branched $\beta$-(I $\rightarrow 6)$-glucan. Glucan preparations from the walls of the yeasts Kloeckera apiculata, Schizosaccharomyces pombe, Saccharomyces fragilis and Saccharomyces fermentati have now been shown to be similarly heterogeneous. Quantitative periodate oxidation and enzymic degradation studies suggest that in these four yeasts, the amount of $\beta$-(I $\rightarrow 6)$-glucan is rather greater than in baker's yeast.
\end{abstract}

\section{INTRODUCTION}

Although the polysaccharide components of yeast walls are usually described in terms of glucan, glycogen, mannan and chitin (see for example Northcote, 1963; Phaff, 1963), recent studies have shown that the glucan component of baker's yeast (Saccharomyces cerevisiae) is heterogeneous (Bacon \& Farmer, I968; Bacon, Farmer, Jones \& Taylor, I969; Manners \& Masson, 1969). The major part is an insoluble branched $\beta$-(I $\rightarrow 3)$-glucan of high molecular weight (having a degree of polymerization (DP) of about 1500 ) and containing about $3 \%$ of $\beta$-(I $\rightarrow 6)$-glucosidic inter-chain linkages (Manners, Masson \& Patterson, $\mathrm{I} 973 a$ ). The minor constituent (about $\mathrm{I} 5 \%$ ) is a soluble branched $\beta$-(I $\rightarrow 6$ )-glucan having a DP of 130 to 140 , and containing about $14 \%$ of $\beta$-(I $\rightarrow 3)$-glucosidic inter-chain linkages (Manners et al. $1973 b$ ). Neither of these structures is in agreement with those originally proposed by (i) Bell \& Northcote (I950) who suggested that yeast glucan was a branched $\beta$-(I $\rightarrow 3$ )-glucan with $\beta$-(I $\rightarrow 2)$-glucosidic inter-chain linkages, (ii) Peat, Whelan \& Edwards (1958) who considered the glucan to be linear and to contain certain sequences of $\beta$-(I $\rightarrow 3)$ - and $\beta$-(I $\rightarrow 6$ )-glucosidic linkages, (iii) Misaki et al. (I968) who postulated a branched structure based on a 'backbone' of $\beta$-(I $\rightarrow 6)$-linked glucose residues, to which were attached linear chains containing about $8 \beta$-(I $\rightarrow 3)$-linked glucose residues. These last three suggestions were made before the heterogeneity of baker's yeast glucan was known. Nevertheless, the various structures are one consequence of the difficulties involved in examining an insoluble polymeric carbohydrate whose composition cannot be readily determined and whose physical nature makes the standard techniques of carbohydrate chemistry less effective. It was therefore desirable to examine glucan preparations in addition to the one from commercial baker's yeast, and we now describe the results obtained with four species of yeast. 


\section{METHODS}

Analytical methods. Reducing sugars were measured colorimetrically using an alkaline copper reagent (Somogyi, I952). Descending paper chromatograms were developed in either solvent I: ethyl acetate - pyridine - water (I0:4:3, by vol.); or solvent 2 : ethyl acetate acetic acid $-90 \%$ formic acid - water (I $8: 3: 1: 4$, by vol.).

Total acid hydrolysis of glucans was carried out at $100{ }^{\circ} \mathrm{C}$ using $90 \%$ formic acid for $2 \mathrm{~h}$ followed by $\mathrm{I} \cdot 5 \mathrm{M}$-sulphuric acid for $3 \mathrm{~h}$ as described by Peat et al. (1958). The formic acid was removed by repeated evaporation, before the treatment with sulphuric acid. The hydrolysates were neutralized with barium carbonate, and deionized with mixed Amberlite IR-20 and IR-45 resins prior to paper-chromatographic analysis. For partial acid hydrolysis, $90 \%$ formic acid for $30 \mathrm{~min}$ followed by $0.22 \mathrm{M}$-sulphuric acid for $\mathrm{I} \mathrm{h}$ at $100{ }^{\circ} \mathrm{C}$ was used.

The enzymic degradation of the glucans was carried out using a bacterial endo- $\beta$ - $(\mathrm{I} \rightarrow 3)$ glucanase preparation, provided by Glaxo Research Ltd, Greenford, Middlesex. Details of the specificity of the enzyme have been given elsewhere (Manners \& Wilson, 1973). In qualitative experiments, glucan (Io $\mathrm{mg}$ ) was incubated with enzyme (5 $\mathrm{mg}$ ) dissolved in 25 mM-sodium citrate buffer, $\mathrm{pH} 5^{\circ} \circ(\mathrm{I} \mathrm{ml})$, at $40^{\circ} \mathrm{C}$. For quantitative assays, glucan $(20 \mathrm{mg})$ was incubated with enzyme $(35 \mathrm{mg})$ in buffer $(30 \mathrm{ml})$ at $40^{\circ} \mathrm{C}$. Further enzyme $(15 \mathrm{mg})$ was added after 9 days' and again after $\mathrm{I} 2$ days' incubation. The reducing power was determined at intervals; the results are corrected for the slight reducing power of the enzyme preparation.

Glucan samples were oxidized with periodate at room temperature ( 18 to $20^{\circ} \mathrm{C}$ ) in the absence of light. For measurement of the reduction of periodate using a spectrophotometric method (Aspinall \& Ferrier, 1957), the glucan (50 to $100 \mathrm{mg}$ ) was treated with $36 \mathrm{~mm}-$ sodium metaperiodate $(25 \mathrm{ml})$ with continuous shaking, for $190 \mathrm{~h}$ and samples removed at intervals for analysis. For measurement of the production of formic acid, glucans (about I50 mg) were oxidized with $0 . \mathrm{I} \mathrm{M}$-sodium metaperiodate $(50 \mathrm{ml}$; previously adjusted to $\mathrm{pH} 5 \cdot 8$ ), and the formic acid content of samples determined by titration to $\mathrm{pH} 5.8$ with 9.3 mM-sodium hydroxide solution under nitrogen (Manners \& Wright, 196I). After about $25 \mathrm{~h}$, both analytical results became linear with respect to time, so that the results could be extrapolated to zero time to enable the initial amount of periodate reduced or formic acid liberated to be calculated. Hence, any errors due to over-oxidation could be minimized.

Cultivation of the yeasts. The following yeasts were grown aerobically at $25{ }^{\circ} \mathrm{C}$ and $\mathrm{pH} 5.5$ in a medium containing $\mathrm{I} \%$ glucose, $0.2 \%$ yeast extract (Oxoid L 20 ), $0.5 \%$ ammonium sulphate, $0.5 \%$ potassium dihydrogen phosphate, and $0 . \mathrm{I} \%(\mathrm{v} / \mathrm{v})$ aqueous salt solution: Kloeckera apiculata (NCYC36), Schizosaccharomyces pombe (NCYC535), Saccharomyces fragilis (NCYC IOO) and $S$. fermentati (NCYCI6I). The salt solution contained $5 \% \mathrm{MgSO}_{4}$. $7 \mathrm{H}_{2} \mathrm{O}, \mathrm{I} \% \mathrm{CaCl}_{2} \cdot 2 \mathrm{H}_{2} \mathrm{O}, \mathrm{I} \% \mathrm{FeSO}_{4} \cdot 7 \mathrm{H}_{2} \mathrm{O}$ and I $\%$ of $\mathrm{KCl}$. A $500 \mathrm{ml}$ bottle containing $250 \mathrm{ml}$ medium was inoculated from a stock culture and incubated at $25^{\circ} \mathrm{C}$ for 2 days. This starting culture was used to inoculate $\mathrm{I} 51$ of medium in a 201 bottle, which was incubated in a water bath at $25^{\circ} \mathrm{C}$ for 2 days. The culture was aerated and agitated by sterile air at $0.8 \mathrm{l} / \mathrm{min}$ through a sintered glass diffuser at the base of the bottle.

Preparation and fractionation of yeast walls. The organisms were separated from the growth medium by continuous centrifugation at 2 I $000 \mathrm{~g}$, washed three times with water, and fractionated by successive extraction with hot dilute sodium hydroxide followed by hot dilute acetic acid and hot water (Fig. I). The general procedure follows that of Bell \& Northcote (1950), as modified by Peat et al. (I958). The yeast was suspended in $6 \%$ sodium hydroxide $(200 \mathrm{ml})$ and stirred at 50 to $60{ }^{\circ} \mathrm{C}$ for $3 \mathrm{~h}$. The suspension was diluted with water ( $\left.1300 \mathrm{ml}\right)$ at $60^{\circ} \mathrm{C}$, allowed to cool, and the insoluble material isolated by centrifugation. This residue 


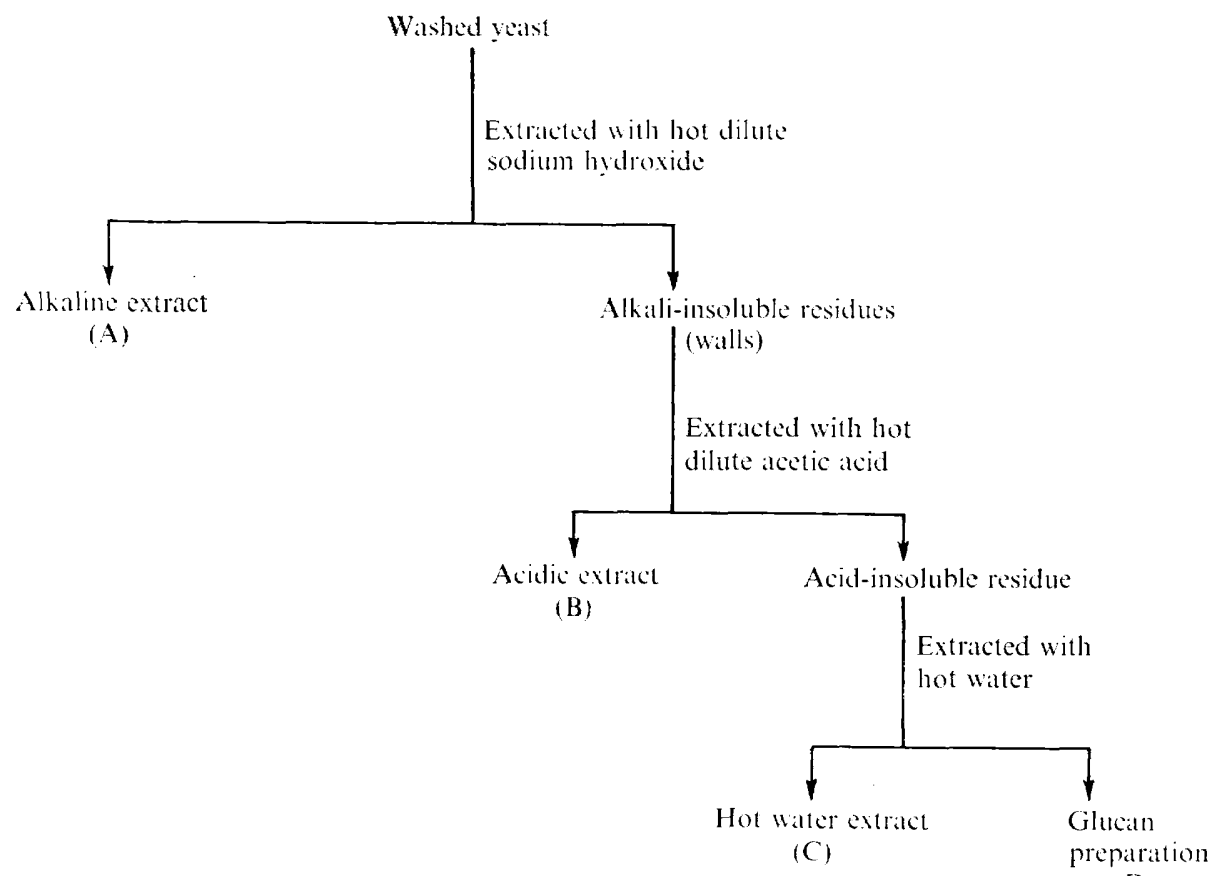

(D)

Fig. I. Scheme for the fractionation of yeast walls.

was suspended in $3 \%$ sodium hydroxide $(300 \mathrm{ml})$ and stirred at 18 to $20{ }^{\circ} \mathrm{C}$ for $18 \mathrm{~h}$. An equal volume of water was added and the mixture centrifuged. The residue was suspended in water $(300 \mathrm{ml})$, heated to $80^{\circ} \mathrm{C}$ and passed through a sintered glass filter (porosity I) to remove large particles. The suspension was adjusted to $\mathrm{pH} 4.5$ with acetic acid and centrifuged. The residue was again suspended in $3 \%$ sodium hydroxide $(200 \mathrm{ml})$ and stirred at $80^{\circ} \mathrm{C}$ for $2 \mathrm{~h}$. Water (I00 $\mathrm{ml}$ ) was added, the $\mathrm{pH}$ again adjusted to 4.5 and the wall material collected by centrifugation. The wall material was then stirred with $0.5 \mathrm{M}$-acetic acid ( $100 \mathrm{ml}$ ) at 70 to $80^{\circ} \mathrm{C}$ for $\mathrm{I} \mathrm{h}$ and allowed to cool. The resulting gelatinous solid was stirred with water at 75 to $80^{\circ} \mathrm{C}$ for $\mathrm{I} h$, centrifuged, and subjected to a second extraction with acetic acid and water. The residue was suspended in $0.02 \mathrm{M}$-sodium acetate $(100 \mathrm{ml})$ and autoclaved at $132{ }^{\circ} \mathrm{C}$ and $27 \mathrm{lb} / \mathrm{in}^{2}$ for $\mathrm{I} h$ to release glycogen. The resulting solid was dispersed in water, centrifuged, and washed six times with water. The pellet was again suspended in $0.0 \mathrm{I} \mathrm{M-}$ sodium acetate $(\mathrm{I} 50 \mathrm{ml})$, autoclaved for $\mathrm{I} h$ and the residue washed three times with water. The residue was then autoclaved for a further $\mathrm{I} \mathrm{h}$ at $132{ }^{\circ} \mathrm{C}$, stirred with water at $20{ }^{\circ} \mathrm{C}$ for $60 \mathrm{~h}$, collected by centrifugation, washed twice with water and ethanol, and finally with ether and petroleum ether (b.p. 60 to $80{ }^{\circ} \mathrm{C}$ ).

Analysis of the alkaline extracts $(A)$ and acetic acid extracts $(B)$. Samples $(15 \mathrm{ml})$ of the alkaline extracts A from each of the four yeasts were dialysed for $24 \mathrm{~h}$ against running tap water, to remove sodium hydroxide. The dialysed extracts were made $\mathrm{I} \cdot 5 \mathrm{M}$ with respect to sulphuric acid and heated at $100{ }^{\circ} \mathrm{C}$ for $4 \mathrm{~h}$. The hydrolysates were neutralized and deionized, and examined by paper chromatography in both solvents $\mathrm{I}$ and 2 .

A portion of each acetic acid extract $B(2 \mathrm{mg})$ was partially hydrolysed with $0.5 \mathrm{M}$-sulphuric acid for $\mathrm{I} h$ at $100{ }^{\circ} \mathrm{C}$, neutralized, and then examined by paper chromatography (solvent $\mathrm{I}$ ). 
Table I. Fractionation of yeast wall preparations

$\begin{array}{lcccc}\text { Yeast } & \begin{array}{c}\text { Wt of washed } \\ \text { organisms }(\mathrm{g})\end{array} & \overbrace{\mathrm{B}(\mathrm{mg})} & \mathrm{C}(\mathrm{mg}) & \mathrm{D}(\mathrm{g}) \\ \begin{array}{c}\text { Kloeckera apiculata } \\ \text { (NCYC 36) }\end{array} & 100 & 390 & \mathrm{I} 20 & \mathrm{I} \cdot 85 \\ \begin{array}{c}\text { Schizosaccharomyces pombe } \\ \text { (NCYC 535) }\end{array} & 150 & 120 & 69 & 2 \cdot 7 \mathrm{I} \\ \begin{array}{c}\text { Saccharomyces fragilis } \\ \text { (NCYC I00) }\end{array} & 150 & 460 & 23 & 2 \cdot 80 \\ \begin{array}{c}\text { Saccharomyces fermentati } \\ \text { (NCYC I6I) }\end{array} & 150 & 360 & 61 & 3 \cdot 60\end{array}$

Fractions were obtained as shown in Fig. I.

Table 2. Properties of yeast glucan preparations $(D)$

\begin{tabular}{|c|c|c|c|c|}
\hline \multirow[b]{2}{*}{ Yeast } & \multirow[b]{2}{*}{$\begin{array}{c}\text { Enzymic } \\
\text { degradation } \\
(\%)^{*}\end{array}$} & \multicolumn{3}{|c|}{ Periodate oxidation } \\
\hline & & $\begin{array}{l}\text { Reduction } \\
\text { of periodate } \\
\text { (molecular } \\
\text { proportions) }\end{array}$ & $\begin{array}{c}\text { Triol } \\
\text { groups } \\
(\%)\end{array}$ & $\begin{array}{l}\text { No. of glucose } \\
\text { residues/ } \\
\text { triol group }\end{array}$ \\
\hline Kloeckera apiculata & 28 & 0.47 & I 8.4 & $5 \cdot 4$ \\
\hline Schizosaccharomyces pombe & 24 & 0.52 & $22 \cdot 8$ & $4 \cdot 4$ \\
\hline Saccharomyces fragilis & 25 & 0.48 & $19 \cdot 5$ & $5 \cdot \mathrm{I}$ \\
\hline Saccharomyces fermentati & 26 & 0.48 & $18 \cdot 4$ & 5.4 \\
\hline Saccharomyces cerevisiae & 32 & 0.27 & $12 \cdot 7$ & $7 \cdot 9$ \\
\hline Purified $\beta$-( $(\mathrm{I} \rightarrow 3)$-glucan from & 38 & $0 \cdot 12$ & $3 \cdot 2$ & 31 \\
\hline
\end{tabular}

Saccharomyces cerevisiae $\dagger$

* Apparent percentage conversion into glucose, on incubation with bacterial endo- $\beta$-(I $\rightarrow 3$ )-glucanase.

$\dagger$ Data from Manners et al. (1973a).

A second portion of each extract $(4 \mathrm{mg})$ was incubated at $37^{\circ} \mathrm{C}$ for $16 \mathrm{~h}$ with salivary $\alpha$-amylase solution $(5 \mathrm{ml})$, and the enzyme then inactivated by heating at $100{ }^{\circ} \mathrm{C}$ for $10 \mathrm{~min}$. The solutions were then dialysed overnight against tap water and concentrated. The extracts were then partially hydrolysed with acid and examined by paper chromatography.

\section{RESULTS}

There was considerable variation in the relative amounts of the acidic extract $\mathrm{B}$ (mainly soluble glucan and glycogen) and hot water extract $\mathrm{C}$ (other soluble glucan) (Table I).

\section{Examination of the glucan samples $(D)$}

Total acid hydrolysis of these glucan preparations gave glucose and no other monosaccharide (by paper-chromatographic analysis in both solvents) showing that mannan had been effectively removed during the fractionation. Partial acid hydrolysates contained sugars with the $R_{G}$ values of glucose, laminaribiose, laminaritriose, gentiobiose and gentiotriose, and unidentified oligosaccharides of lower $R_{\mathrm{G}}$ value. The chemical characterization of the sugars having the same $R_{\mathbb{G}}$ values in partial hydrolysates of the glucan from baker's yeast has been described elsewhere (Manners et al. 1973a).

Incubation of the glucans with the bacterial endo- $\beta$ - $(\mathrm{I} \rightarrow 3)$-glucanase caused slow hydrolysis, with the liberation of glucose, laminaribiose, laminaritriose and oligosaccharides of lower $R_{\mathrm{a}}$ value (using paper chromatography and solvent I). Gentiobiose was not detected among the hydrolysis products. The apparent percentage conversion into glucose, as deter- 
Table 3. Components of partial acid hydrolysates of acetic acid extracts*

\begin{tabular}{|c|c|c|c|c|c|}
\hline $\begin{array}{l}R_{\mathrm{G}} \text { value } \\
\text { (solvent } \mathrm{I} \text { ) }\end{array}$ & $\begin{array}{l}\text { Probable } \\
\text { identity }\end{array}$ & $\begin{array}{l}\text { Kloeckera } \\
\text { apiculata }\end{array}$ & $\begin{array}{c}\text { Saccharomyces } \\
\text { fermentati }\end{array}$ & $\begin{array}{l}\text { Saccharomyces } \\
\text { fragilis }\end{array}$ & $\begin{array}{l}\text { Schizosaccharo- } \\
\text { myces pombe }\end{array}$ \\
\hline $\mathrm{I} \cdot \mathrm{OO}$ & Glucose & + & + & + & + \\
\hline 0.62 & Maltose & + & + & - & + \\
\hline 0.45 & Gentiobiose & + & + & + & + \\
\hline 0.39 & Maltotriose & + & - & - & + \\
\hline 0.25 & Unknown & + & - & - & + \\
\hline 0.18 & Gentiotriose & + & + & + & + \\
\hline 0.07 & Gentiotetraose & + & + & + & + \\
\hline 0.03 & Gentiopentaose & + & + & + & + \\
\hline
\end{tabular}

* The symbols + and - indicate the presence and absence of the various sugars, without having any quantitative significance.

mined by reducing power measurements, after digestion for 14 days is shown in Table 2. The extent of enzymolysis was significantly less than with the baker's yeast glucan.

All four samples of glucan reduced substantially more periodate and produced signifcantly more formic acid than the baker's yeast sample (Table 2).

\section{Examination of the alkaline extracts $A$}

All four acid hydrolysates contained substantial amounts of glucose and mannose, and trace amounts of a pentose with an $R_{\mathrm{G}}$ value similar to D-ribose. In addition, the hydrolysate from Schizosaccharomyces pombe contained a trace amount of a hexose with the $R_{G}$ value of D-galactose.

\section{Examination of the acetic acid extracts $B$}

The sugars present in partial acid hydrolysates are recorded in Table 3. By analogy with control experiments carried out on baker's yeast, it is clear that the extracts contain a $\beta$-(I $\rightarrow 6)$-glucan which is contaminated to varying extents with glycogen. The extract from Saccharomyces fragilis contained the least glycogen, and that from Schizosaccharomyces pombe the most.

On pretreatment of the extracts with $\alpha$-amylase followed by partial acid hydrolysis, the results were similar to those in Table 3 except that maltose and maltotriose were absent from all hydrolysates, showing that the contaminating glycogen had been removed by the $\alpha$-amylolysis. A trace of mannose $\left(R_{\mathrm{G}} \mathrm{I} \cdot \mathrm{I} 4\right)$ was present in the extracts, except that of Kloeckera apiculata, indicating that a trace of mannan was probably present in the original extracts. There was also evidence for a pentose $\left(R_{\mathrm{G}} \mathrm{I} \cdot 30\right)$ and a hexose (possibily galactose, having $R_{\mathrm{G}} 0.87$ ) in the extracts, but these are not considered to be relevant to the present discussion.

\section{DISCUSSION}

Wall preparations of baker's yeast contain a complex mixture of polysaccharides and protein (Bacon et al. 1969; MacWilliam, 1970). By extraction with alkali, most of the mannan and protein is selectively removed; extraction with hot acetic acid then removes soluble glucan, which is a mixture of glycogen and $\beta$ - $(\mathrm{I} \rightarrow 6)$-glucan. Further quantities of glycogen can be obtained by autoclaving the acetic acid-insoluble residue, and the final product has previously been regarded as 'yeast glucan'. However, this material is still heterogeneous (Manners et al. $1973 a, b$ ). 
Although polysaccharide fractionation experiments have not been carried out, the present results strongly suggest that the 'yeast glucan' prepared from the four yeasts is similarly heterogeneous. For example, the presence of gentiotriose in the partial acid hydrolysates is evidence for a $\beta$ - $(\mathrm{I} \rightarrow 6)$-glucan component, since this trisaccharide does not arise from the partial hydrolysis of yeast $\beta$-(I $\rightarrow 3)$-glucan (Manners et al. 1973a). The quantitative data in Table 2 indicates that the $\beta$-( $\mathrm{I} \rightarrow 6)$-glucan content of the four yeasts is significantly greater than that of baker's yeast. The extent of enzymic degradation is appreciably lower for these yeasts and hence the proportion of enzymically resistant linkages (i.e. $\beta$-(I $\rightarrow 6)$ linkages) must be greater.

This view is substantiated by the periodate oxidation results. The amount of periodate reduced is a measure of the content of $\alpha$-glycol groups, which may be present as both diol and triol groups. In a branched $\beta$ - $(\mathrm{I} \rightarrow 3)$-glucan, the latter are present only at non-reducing and reducing terminal residues whilst diol groups are usually absent, so that the overall reduction of periodate is about 0.1 molecular proportions (see Table 2). With the glucan preparations from the four yeasts, the reduction of periodate approximates to 0.5 molecular proportions showing the presence of a significant number of periodate-sensitive residues. A glucan containing only $\beta$-(I $\rightarrow 6)$-glucosidic linkages would reduce about $2 \cdot 0$ molecular proportions of periodate (Manners et al. $1973 \mathrm{~b}$ ).

During periodate oxidation, formic acid may be liberated from non-reducing terminal residues, and non-terminal residues linked only through $\mathrm{CI}_{\mathrm{I}}$ and $\mathrm{C} 6$. In the purified $\beta$-(I $\rightarrow 3$ )glucan from baker's yeast the latter are absent, and the production of formic acid amounts to about $\mathrm{I}$ mol per 30 glucose residues. This result may be compared with the value of I per 8 residues for the original yeast glucan (Table 2), the difference representing the formic acid arising from the ( $\mathrm{I} \rightarrow 6$ )-linked glucose residues. The production of about $\mathrm{I}$ mol of formic acid per 5 glucose residues from the glucan preparations from the four yeasts would confirm the above suggestion for a higher content (about $20 \%$ ) of $\beta$-(I $\rightarrow 6$ )-glucan than in baker's yeast. The $\beta$-(I $\rightarrow 6)$-glucan is not confined to the insoluble residue remaining after exhaustive extraction of the yeast walls, but is also present in the acetic acid extracts (Table 3), and is an impurity in preparations of yeast glycogen made by standard methods (Evans \& Manners, I97I).

The function of the $\beta$-( $\mathrm{I} \rightarrow 6)$-glucan is not yet known. Since it is soluble and of low molecular weight it might be a reserve rather than a structural material, although this function would duplicate that generally assigned to glycogen. An alternative possibility is that it serves as a filling material or plasticizer within the relatively rigid wall framework provided by the $\beta$-(I $\rightarrow 3)$-glucan. Its function could be physically to prevent excessive hydrogen bonding or other means of aggregation of essentially linear segments of chains of $\beta$ - $(\mathrm{I} \rightarrow 3)$ linked D-glucose residues, so that the wall retained some measure of flexibility as is required, for example, for wall expansion during growth. The extraction of the $\beta$ - $(I \rightarrow 6)$-glucan from the walls with dilute acetic acid may be analogous to the preparation of 'hydroglucan' by boiling yeast walls for $2 \mathrm{~h}$ with $2 \%$ hydrochloric acid (Kreger, I954). In contrast to normal yeast 'glucan', the product gave a sharp X-ray diagram and had a fibrillar structure on electron microscopy. This change in physical properties would be expected if a more soluble and amorphous $\beta$-(I $\rightarrow 6)$-glucan component had been leached out of the walls. Hydroglucan may therefore be similar to the separated high molecular weight $\beta$ - $(\mathrm{I} \rightarrow 3)$ glucan described previously (Manners et al. 1973a). Previous enzymic degradation studies on yeast walls have shown that samples from different species varied in their relative susceptibility to $\beta$-(I $\rightarrow 3$ )- and $\beta$-(I $\rightarrow 6$ )-glucanases (Phaff, $\mathrm{I} 97 \mathrm{I})$. These results may now be explained in terms of some variation in the relative amounts of $\beta$ - $(\mathrm{I} \rightarrow 3)$ - and $\beta$ - $(\mathrm{I} \rightarrow 6)$ - 
glucan. This conclusion and the present results suggest that the heterogeneous nature of yeast glucan is typical of several, but not necessary all, species of yeast.

We are indebted to Dr I. Campbell for his collaboration in growing the yeasts, to the Eda, Lady Jardine Charitable Trust for the award of a research fellowship to A.J.M. and to the Science Research Council for an equipment grant and a research studentship to J.C.P.

\section{REFERENCES}

Aspinall, G. O. \& Ferrier, R. J. (1957). A spectrophotometric method for the determination of periodate consumed during the oxidation of carbohydrates. Chemistry \& Industry, 1216.

BACON, J.S. D. \& FARMer, V. C. (1968). The presence of a predominantly $\beta$-(I $\rightarrow 6)$-component in preparations of yeast glucan. Biochemical Journal r10, 34-35P.

BACON, J. S. D., FARMER, V. C., JONES, D. \& TAYlor, I. F. ( I969). The glucan components of the cell wall of baker's yeast (Saccharomyces cerevisiae) considered in relation to its ultrastructure. Biochemical Journal II4, 557-567.

Bell, D. J. \& NorthCote, D. H. (1950). The structure of a cell-wall polysaccharide of baker's yeast. Journal of the Chemical Society, 1944-1947.

EVANS, R. B. \& MANNERS, D. J. (I97I). Observations on the purity of some yeast glycogen preparations. Biochemical Journal 125, 3 IP.

KREGER, D. R. (1954). Observations on cell walls of yeast and some other fungi by X-ray diffraction and solubility tests. Biochimica et biophysica acta $\mathbf{1 3}, \mathrm{I}-9$.

MACWILliam, I. C. (1970). The structure, synthesis and functions of the yeast cell wall - a review. Journal of the Institute of Brewing 76, 524-535.

Manners, D. J. \& Masson, A. J. (I969). The structures of two glucans from yeast cell walls. FEBS Letters 4, I 22-I 24 .

Manners, D. J., Masson, A. J. \& Patterson, J. C. (I973a). The structure of a $\beta$-(I $\rightarrow 3$ )-D-glucan from yeast cell walls. Biochemical Journal I35, I9-30.

Manners, D. J., Masson, A. J., Patterson, J. C., Bjorndal, H. \& Lindberg, B. (I973 b). The structure of a $\beta-(1 \rightarrow 6)$-D-glucan from yeast cell walls. Biochemical Journal r35, 3I-36.

MANners, D. J. \& Wilson, G. (I973). Some properties of a bacterial endo- $\beta$-(I $\rightarrow 3$ )-glucanase system. Biochemical Journal r35, I I-I 8 .

MANNERS, D. J. \& Wright, A. (I96r). End-group assay of glycogens by oxidation with sodium metaperiodate. Journal of the Chemical Society, $268 \mathrm{I}-2684$.

Misaki, A., Johnson, J., Kirkwood, A., Scaletti, J. V. \& Smith, F. (i 668). Structure of the cell-wall glucan of yeast (Saccharomyces cerevisiae). Carbohydrate Research 6, 150-I64.

Northcote, D. H. (1963). The structure and organization of the polysaccharides of yeast. Pure and Applied Chemistry 7, 669-675.

Peat, S., Whelan, W. J. \& Edwards, T. E. (1958). Polysaccharides of baker's yeast. II. Yeast glucan. Journal of the Chemical Society, 3862-3868.

Phaff, H. J. (1963). Cell wall of yeasts. Annual Reviews of Microbiology I7, I5-30.

Phaff, H. J. (197I). Structure and biosynthesis of the yeast cell envelope. In The Yeasts, vol. 2, pp. 135-210. Edited by A. J. Rose and J. S. Harrison. London and New York: Academic Press.

Somogyi, M. (1952). Notes on sugar determination. Journal of Biological Chemistry 195, 19-23. 